\title{
Strategi Pemasaran Pembiayaan Arrum Haji Dalam Meningkatakan Jumlah Nasabah di Unit Pegadaian Syariah (UPS) Cirebon Bisnis Center
}

\author{
Oktavia Fajrin $^{1}$ Afif Muamar ${ }^{2}$ \\ Institut Agama Islam Negeri Syekh Nurjati Cirebon \\ oktavianvya@gmail.com¹Afifmuamar85@gmail.com²
}

\begin{abstract}
Hajj Financing for Micro Business (Arrum) Hajj in Pegadaian Syariah is relatively new, because this product was only launched in 2016. For this new product an introduction is needed to be able to attract the interest of the community. Therefore, this study aims to determine marketing strategies, the mechanism of Arrum Hajj financing registration, and to determine customer responses to Arrum Hajj products at the Pegadaian Syariah Cirebon Business Center. This study used a qualitative method with a descriptive analytical approach, and this research resulted in a marketing strategy conducted by the CBC Sharia Pawnshop Unit using a $4 p$ strategy, namely Product, Price, Place, and Promotion. The results of this study found that the price and place strategy had been determined by the head office and the Pegaadian Sharia branch office. While the product strategy has been going very well, by providing services and comfort, as well as promotion strategies carried out by sharia pawnshops are quite diverse such as holding seminars, socialization, cross selling techniques and so on. Hajj arrum registration mechanism is in accordance with existing procedures. And the response given by Arrum Hajj financing customers is very good, because with the availability of Arrum Hajj products can ease the burden on customers and can quickly get a portion of Hajj.
\end{abstract}

Keywords: Sharia Pawnshop, Arrum Hajj, Marketing Strategy, and Customer Response.

\begin{abstract}
Abstrak
Pembiayaan Arahan untuk Usaha Mikro (Arrum) Haji di Pegadaian Syariah masih terbilang baru, karena produk ini baru diluncurkan pada tahun 2016. Untuk produk baru ini diperlukan adanya pengenalan agar mampu menarik minat dari masyarakat. Oleh karena itu, penelitian ini bertujuan untuk mengetahui stratergi pemasaran, mekanisme pendaftaran pembiayaan Arrum Haji, dan untuk mengetahui respon nasabah terhadap produk Arrum Haji di Pegadaian Syariah Cirebon Bisnis Center. Penelitian ini menggunakan metode kualitatif dengan pendekatan deskriptif analitis, dan penelitian ini menghasilkan strategi pemasaran yang dilakukan Unit Pegadaian Syariah CBC yakni menggunakan strategi 4p, yakni Product, Price, Place, dan Promotion. Hasil penelitian ini didapatkan bahwa strategi price dan place sudah ditetapkan oleh kantor pusat dan kantor cabang Pegaadian Syariah. Sedangkan strategi product sudah berjalan sangat baik, dengan memberikan pelayanan dan kenyamanan, serta strategi promotion yang dilakukan pegadaian syariah cukup beragam seperti diadakannya seminar, sosialisasi, teknik cross selling dan sebagainya. Mekanisme pendaftaran arrum haji telah sesuai dengan prosedur yang ada. Dan respon yang diberikan oleh nasabah pembiayaan Arrum Haji sangat baik, karena dengan adanya produk Arrum Haji dapat meringankan beban nasabah serta dapat dengan cepat mendapatkan porsi haji.
\end{abstract}


Strategi Pemasaran Pembiayaan Arrum Haji Dalam Meningkatakan Jumlah Nasabah Di Unit Pegadaian Syariah (UPS) Cirebon Bisnis Center

Kata Kunci: Pegadaian Syariah, Arrum Haji, Strategi Pemasaran, dan Respon Nasabah.

\section{LATAR BELAKANG}

Kini persaingan dalam lembaga keuangan sangat ketat baik lembaga keuangan konvensional maupun lembaga keuangan syariah. Ketatnya persaingan namun dibarengi dengan pertumbuhan yang sangat pesat pula. Hal ini dapat dilihat dalam pengembangan produk yang dilakukan oleh setiap lembaga keuangan baik konvensional maupun lembaga keuangan syariah dan lembaga keuangan perbankan maupun non perbanakan. Pengembangan produk ini dilakukan untuk mempertahankan daya saing yang dimiliki setiap lembaga keuangan. Apabila lembaga keuangan tidak mengikuti perkembangan zaman dan tidak adanya inovasi baru maka dipastikan lembaga tersebut tidak akan bertahan lama karena ketidakmampuannya untuk bersaing.

Pada lembaga keuangan syariah non perbankan yakni Pegadaian Syariah kini memiliki beberapa inovasi baru dalam hal pengembangan produk diantaranya terdapat produk tabungan emas, produk amanah, produk ar Rahn untuk usaha mikro (ARRUM), produk rahn tasjily tanah dan masih banyak lagi, namun tidak menghilangkan esensinya sendiri yaitu menggadaikan. Pada produk ARRUM ini merupakan suatu produk yang diluncurkan oleh Pegadaian Syariah agar nasabah Pegadaian dapat mewujudkan mimpinya. Produk ARRUM terbagi kedalam dua jenis yaitu Arrum BPKB, dan Arrum Haji.

Produk Arrum Haji merupakan solusi bagi umat muslim yang ingin menunaikan ibadah haji ke tanah suci namun tidak memiliki dana yang cukup untuk mendaftar haji. Maka dari itu Pegadaian Syariah meluncurkan produk ini agar dapat meringankan beban para umat muslim yang berkeinginan menunaikan ibadah haji dengan cara menggadaikan sejumlah logam mulia maupun emas perhiasan yang kemudian langsung mendapatkan porsi haji.

Setiap produk baru memerlukan adanya perencanaan pemasaran agar pada saat memasarkan produk tersebut dapat dipahami dengan mudah dan mampu menarik pelanggan untuk membeli produk tersebut. Dalam hal ini belum banyak nasabah yang tahu dan paham mengenai produk Arrum Haji yang ada di Pegadaian Syariah. Menurut data yang didapatkan dari kantor Pegadaian Unit Pelayanan Syariah Cirebon Bisnis Center (CBC) jumlah nasabah ARRUM Haji dari tahun 2016 sebanyak 12 nasabah. Target yang ditetapkan untuk jumlah nasabah sebanyak 8 orang per tahunnya, namun tahun ini baru 4 orang yang terdaftar sebagai nasabah ARRUM Haji.

Berdasarkan latar belakang di atas maka penulis akan memfokuskan penelitian mengenai permasalah sebagai berikut, pertama, 
Konstruksi At-Tas'īr Al-'Adl dalam Dialektika Pemikiran Ibnu Taimiyah Dan Ibnu Khaldun

bagaimanakah strategi pemasaran produk pembiayaan ARRUM Haji di Unit Pegadaian Syariah Cirebon Bisnis Center? Kedua, bagaimanakah mekanisme pelaksaan pendaftaran Arrum Haji? Ketiga, bagaimanakah respon nasabah terhadap produk pembiayaan ARRUM Haji?

\section{LITERATURE REVIEW}

Walaupun produk Arrum Haji di Pegadaian Syariah masih terbilang baru, namun telah banyak yang meneliti khususnya dalam pembahasan mengenai strategi pemasaran dan respon. Peneliti menggunakan penelitian tersebut sebagai bahan perbandingan dan untuk menjadi pijakan dasar penelitian ini. Berikut beberapa penelitian terkait permasalahan yang dikaji, yaitu pertama, Muhammad Fuad yang berjudul "Analisis Peran Pembiayaan Oleh Pegadaian Syariah Bagi Pengembangan UMKM (Studi Kasus Produk Ar-Rum di Kota Langsa)". Penelitian ini menjelaskan bahwa pegadaian syariah merupakan bagian dari lembaga keuangan non-bank di Indonesia yang berfungsi menyalurkan pembiayaan melalui pemberian pinjaman uang berdasarkan prinsip gadai kepada sektor usaha yang membutuhkan. UMKM merupakan sektor usaha yang utamanya mengalami kendala akses pembiayaan dalam aspek jaminan serta legalitas dan tata administrasi. Produk Ar-Rum diluncurkan oleh Pegadaian Syariah menggunakan sistem fidusia, dengan harapan membantu kebutuhan sektor usaha tersebut. Penelitian ini bertujuan menganalisis bagaimana peranan produk pembiayaan Ar-Rum dalam pengembangan UMKM. Data primer dikumpulkan melalui kuesioner dan wawancara pada 100 nasabah, lalu dianalisis menggunakan metode deskriptif dan stastistik parametrik. Hasil analisis deskriptif menunjukkan bahwa mayoritas responden menyatakan sangat setuju ataupun setuju bahwa Ar-Rum bermanfaat membantu pengembangan maupun keberlanjutan usaha mereka, sementara hasil uji statistik menyatakan bahwa produk ArRum berpengaruh secara positif dan signifikan terhadap pengembangan UMKM (Fuad, 2018).

Kedua, Penelitian yang dilakukan oleh Jauhariatuzzuhdiyah, dengan judul "Pengaruh Prosedur Pembiayaan Arrum Haji Terhadap Keputusan Nasabah Dalam Menggunakan Jasa Pada Pegadaian Syariah (Study Kasus Pegadaian Syariah Cabang Balauran Dan Pegadaian Syariah Cabang Sidoarjo)". Penelitian ini menghasilkan bahwa terdapat pengaruh yang signifikan antara prosedur pembiayaan terhadap keputusan nasabah menggunakan produk Arrum Haji di Pegadaian Syariah Cabang Blauran Surabaya dan Pegadaian Syariah Cabang Sidoarjo. Sebaiknya PT Pegadaian Syariah dapat lebih meningkatkan kemudahan dari segi persyaratan dan realisasi pembiayaan, karena persaingan dalam usaha pembiayaan haji semakin marak dan ketat, maka dari itu Pegadaian Syariah baiknya lebih meningkatkan prosedur pembiayaan sebagai 
Strategi Pemasaran Pembiayaan Arrum Haji Dalam Meningkatakan Jumlah Nasabah Di Unit Pegadaian Syariah (UPS) Cirebon Bisnis Center

strategi promosi untuk menarik dan meningkatkan nasabah yang menggunakan produk Arrum Haji di Pegadaian syariah Cabang Blauran Surabaya dan Pegadaian Syariah Cabang Sidoarjo (Jauhariyah, 2018).

Ketiga, Penelitian yang dilakukan oleh Wiki Fatmala, dengan judul "Analisis Strategi Pemasaran Poduk Arrum Haji dalam Meningkatkan Jumlah Nasabah (Study Kasus Pegadaian Unit Pelayanan Syariah Way Halim)". Hasil dari penelitian ini yaitu bahwa kendala yang dihadapi dalam memasarkan produk arrum haji adalah terletak pada strategi promosi pihak pegadaian unit pelayanan syariah way halim itu sendiri yang karyawannya juga kurang paham dengan produk arrum haji. Strategi pemasaran di Pegadaian Unit Pelayanan Syariah Way Halim menerapkan bauran pemasaran (marketing mix), yaitu strategi produk, strategi harga, strategi tempat, dan strategi promosi (Fatmala, 2018).

Dari hasil pemaparan penelitian di atas, terdapat persamaan pembahasan yang akan dibahas dalam penelitian ini yaitu membahas mengenai strategi pemasaran dan prosedur pembiayaan terhadap produk pembiayaan Arum Haji dalam meningkatkan jumlah nasabah dengan menggunakan akad rahn emas.

\section{METODOLOGI PENELITIAN}

Penelitian ini menggunakan metode penelitian kualitatif, yaitu penelitian yang dilakukan secara mendalam dengan melihat berbagai aspek dari sasaran penelitian (Toto dan Budi, 2016). Data yang didapatkan bukan berupa angka-angka melainkan data yang didapatkan langsung dari hasil observasi dan wawancara dengan menyiapkan beberapa pertanyaan. Dan jenis penelitian ini adalah penelitian lapangan (field research), yaitu dengan mengamati dan berpartisipasi secara langsung terhadap objek penelitian.

\section{Sumber Data Penelitian}

Sumber data yang digunakan dalam penelitian ini ada dua yaitu, data primer dan data sekunder. Data primer adalah data yang diperoleh langsung dari sumbernya, diambil dengan cara wawancara secara langsung dengan pihak pegadaian syariah. Data Sekunder merupakan sumber data penelitian yang diperoleh peneliti secara tidak langsung melalui media perantara (diperoleh dan dicatat oleh pihak lain). Data sekunder yang dibutuhkan dalam penelitian ini seperti buku-buku dan literatur yang berkaitan dengan penelitian ini.

\section{Teknik Pengumpulan Data}

\section{Metode Observasi}

Metode observasi adalah metode yang dilakukan untuk mengetahui sesuatu yang sedang terjadi atau sedang dilakukan dan merasa perlu untuk dilihat sendiri (Afrizal, 2016). Teknik ini digunakan untuk mendapatkan fakta-fakta empirik yang tampak 
Konstruksi At-Tas'īr Al-'Adl dalam Dialektika Pemikiran Ibnu Taimiyah Dan Ibnu Khaldun

(kasat mata) dan guna memperoleh dimensi-dimensi baru untuk pemahaman konteks maupun fenomena yang diteliti (Widodo, 2017).

\section{Metode Wawancara}

Wawancara adalah kegiatan tanya jawab untuk memperoleh informasi atau data. Wawancara dapat dilakuan secara open ended (peneliti bertanya kepada responden kunci tentang fakta-fakta suatu peristiwa dan opini yang ada), terfokus (responden diwawancarai dalam waktu yang pendek), dan terstruktur (menggunakan pertanyaan yang terstruktur) (Widodo, 2017). Dalam hal ini penulis menggunakan metode wawancara untuk mendapatkan informasi mengenai pemasaran arrum haji di Pegadaian Syariah.

\section{Metode Dokumentasi}

Dokumentasi adalah kegiatan pengumpulan data yang dilakukan melalui penelusuran dokumen. Teknik ini dilakukan dengan memanfaatkan dokumen-dokumen tertulis, gambar, foto atau benda-benda lainnya yang berkaitan dengan aspek-aspek yang diteliti (Widodo, 75). Pengumpulan dokumen dilakukan untuk mengecek kebenaran atau ketepatan informasi yang diperoleh dengan melakukan wawancara (Afrizal, 2016).

\section{KONSEP DASAR}

\section{Pegadaian Syariah}

Pegadaian menurut Kitab Undang-Undang Hukum Perdata Pasal 1150 disebutkan "Gadai adalah suatu hak yang diperoleh seorang yang berpiutang atas suatu barang bergerak, yang diserahkan kepadanya oleh seorang berutang atau oleh seorang lain atas namanya, dan yang memberikan kekuasaan kepada orang yang berpiutang itu untuk mengambil pelunasan dari barang tersebut secara didahulukan daripada orang yang berpiutang lainnya, dengan pengecualian biaya untuk melelang barang tersebut dan biaya yang telah dikeluarkan untuk menyelamatkannya setelah barang itu digadaikan, biaya-biaya mana harus didahulukan."

PT Pegadaian sampai saat ini merupakan satu-satunya lembaga formal di Indonesia yang berdasarkan hukum dibolehkan melakukan pembiayaan dengan bentuk penyaluran kredit atas dasar hukum gadai. Tugas pokok PT Pegadaian adalah menjembatani kebutuhan dana masyarakat dengan pemberian uang pinjaman berdasarkan hukum gadai. Tugas tersebut dimaksudkan untuk membantu masyarakat agar tidak terjerat dalam praktik-praktik lintah darat. Kantor pusat PT Pegadaian berkedudukan di Jakarta, dan dibantu oleh kantor daerah, kantor perwakilan daerah, dan kantor cabang. Jaringan usaha PT Pegadaian telah meliputi lebih dari 500 cabang yang tersebar di wilayah Indonesia. 
Strategi Pemasaran Pembiayaan Arrum Haji Dalam Meningkatakan Jumlah Nasabah Di Unit Pegadaian Syariah (UPS) Cirebon Bisnis Center

Pegadaian syariah hadir di Indonesia dengan membentuk unit layanan gadai syariah di beberapa kota di Indonesia. Pegadaian syariah mulai beropersi sejak 2003. Sampai Oktober 2015, jumlah gerai pegadaian syariah mencapai 611 outlet di seluruh Indonesia. Itu terdiri dari 83 cabang dan 528 kantor unit. Jumlah itu kebanyakan terdapat di Pulau Jawa, penyebarannya tidak merata. Padahal cita-citanya, pegadaian ingin mempunyai gerai diseluruh kabupaten (Soemitro, 2009: 399-400).

Hukum gadai syariah dalam hal pemenuhan prinsip-prinsip syariah berpegang pada Fatwa DSN MUI No. 25/DSN-MUI/III/2002 tanggal 26 Juni 2002 tentang rahn yang menyatakan bahwa pinjaman dengan menggadaikan barang sebagai jaminan utang dalam bentuk rahn diperbolehkan, dan Fatwa DSN MUI No. 26/DSN-MUI/III/2002 tentang gadai emas. DSN MUI juga menerbitkan Fatwa No. 68/DSN-MUI/II12008 tentang Rahn Tasjily. Sedangkan dalam aspek kelembagaan tetap menginduk kepada Peraturan Pemerintah Nomor 103 Tahun 2000. Transaksi gadai menurut syariah haruslah memenuhi rukun dan syarat tertentu, yaitu:

1. Rukun gadai, adanya ijab dan qabul, adanya pihak yang berakad yaitu pihak yang menggadaikan (rahin) dan yang menerima gadai (murtahin), adanya jaminan (marhun) berupa barang atau harta, adanya utang (marhun bih).

2. Syarat sah gadai, rahin dan murtahin dengan syarat-syarat kemampuan juga berarti kelayakan seseorang untuk melakukan transaksi pemilikan, setiap orang yang sah melakukan jual beli sah melakukan gadai. Sighat dengan syarat tidak boleh terkait dengan masa yang akan datang dan syarat-syarat tertentu. Utang (marhun bih) dengan syarat harus merupakan hak yang wajib diberikan atau diserahkan kepada pemiliknya, memungkinkan pemanfaatannya bila sesuatu yang menjadi utang itu tidak bisa dimanfaatkan maka tidak sah, harus dikuantifikasi atau dapat dihitung jumlahnya bila tidak dapat diukur atau tidak dikuantifikasi, rahn itu tidak sah. Barang (marhun) dengan syarat harus bisa diperjualbelikan, harus berupa harta yang bernilai, marhun harus bisa dimanfaatkan secara syariah, harus diketahui keadaan fisiknya, harus dimiliki oleh rahin setidaknya harus seizin pemiliknya (Soemitro, 2009: 402).

Di samping itu, menurut Fatwa DSN MUI No. 25/DSNMUI/III/2002 gadai syariah harus memenuhi ketentuan umum berikut:

1. Murtahin (penerima barang) mempunyai hak untuk menahan marhun (barang) sampai semua hutang rahin (yang menyerahkan barang) dilunasi. 
2. Marhun dan manfaatnya tetap menjadi milik rahin. Pada prinsipnya, marhun tidak boleh dimanfaatkan oleh murtahin kecuali seizin rahin, dengan tidak mengurangi nilai marhun dan pemanfaaatannya itu sekedar pengganti biaya pemeliharaan dan perawatannya.

3. Pemeliharaan dan penyimpanan marhun pada dasarnya menjadi kewajiban rahin, namun dapat dilakukan juga oleh murtahin, sedangkan biaya dan pemeliharaan penyimpanan tetap menjadi kewajiban rahin.

4. Besar biaya pemeliharaan dan penyimpanan marhun tidak boleh ditentukan berdasarkan jumlah pinjaman.

5. Penjualan marhun

a. Apabila jatuh tempo, murtahin harus memperingatkan rahin untuk segera melunasi utangnya.

b. Apabila rahin tetap tidak dapat melunasi utangnya, maka marhun dijual paksa/dieksekusi melalui lelang sesuai syariah.

c. Hasil penjualan marhun digunakan untuk melunasi utang, biaya pemeliharaan dan penyimpanan yang belum dibayar serta biaya penjualan.

d. Kelebihan hasil penjualan menjadi milik rahin dan kekurangannya menjadi kewajiban rahin.

Pada dasarnya pegadaian syariah berjalan di atas dua akad transaksi syariah yaitu:

1. Akad rahn, rahn yang dimaksud adalah menahan harta milik si peminjam sebagai jaminan atas pinjaman yang diterimanya, pihak yang menahan memperoleh jaminan untuk mengambil kembali seluruh atau sebagian piutangnya. Dengan akad ini, pegadaian menahan barang bergerak sebagai jaminan atas utang nasabah.

2. Akad ijarah, yaitu akad pemindahan hak guna atas barang dan/atau jasa melalui pembayaran upah sewa, tanpa diikuti dengan pemindahan kepemilikan atas barangnya sendiri. Melalui akad ini dimungkinkan bagi pegadaian untuk menarik sewa atas penyimpanan barang bergerak milik nasabah yang telah melakukan akad.

Akad gadai syariah juga harus memenuhi ketentuan atau persyaratan yang menyertainya, meliputi:

1. Akad tidak mengandung syarat fasid/bathil seperti murtahin mensyaratkan barang jaminan dapat dimanfaatkan tanpa batas. 
Strategi Pemasaran Pembiayaan Arrum Haji Dalam Meningkatakan Jumlah Nasabah Di Unit Pegadaian Syariah (UPS) Cirebon Bisnis Center

2. Marhun bih (pinjaman) merupakan hak yang wajib dikembalikan kepada murtahin dan bisa dilunasi dengan barang yang dirahnkan tersebut. Serta, pinjaman itu jelas dan tertentu.

3. Marhun (barang yang dirahnkan) bisa dijual dan nilainya seimbang dengan pinjaman, memiliki nilai, jelas ukurannya, milik sah penuh dari rahin, tidak terkait dengan hak orang lain, dan bisa diserahkan baik materi maupun pemanfaatannya.

4. Jumlah maksimum dana rahn dan nilai likuidasi barang yang dirahnkan serta jangka waktu rahn ditetapkan dalam prosedur.

5. Rahin dibebani jasa manajemen atas barang berupa biaya asuransi, biaya penyimpanan, biaya keamanan, dan biaya pengelolaan serta administrasi (Soemitro, 2009: 403).

Jenis barang yang dapat diterima sebagai barang jaminan pada prinsipnya adalah barang bergerak, antara lain:

1. Barang-barang perhiasan, yaitu semua perhiasan yang dibuat dari emas, perhiasan perak, platina, baik yang berhiaskan intan, mutiara;

2. Barang-barang elektronik: laptop, TV, kulkas, radio, tape recorder, vcd/dvd, radio kaset;

3. Kendaraan: sepeda, sepeda motor, mobil;

4. Barang-barang rumah tangga;

5. Mesin: mesin jahit, mesin motor kapal;

6. Tekstil;

7. Barang-barang lain yang dianggap bernilai seperti surat-surat berharga baik dalam bentuk saham, obligasi, maupun surat-surat berharga lainnya.

Pegadaian sebagai lembaga keuangan tidak diperkenankan menghimpun dana secara langsung dari masyarakat dalam bentuk simpanan, misalnya giro, deposito, dan tabungan. Untuk memenuhi kebutuhan dananya, PT Pegadaian memiliki sumber-sumber dana sebagai berikut:

1. Modal sendiri;

2. Penyertaan modal pemerintah;

3. Pinjaman jangka pendek dari perbankan; 
Konstruksi At-Tas'īr Al-'Adl dalam Dialektika Pemikiran Ibnu Taimiyah Dan Ibnu Khaldun

4. Pinjaman jangka panjang yang berasal dari Kredit Lunak Bank Indonesia;

5. Dari masyarakat melalui penerbitan obligasi.

Aspek syariah tidak hanya menyentuh bagian operasionalnya saja, pembiayaan kegiatan dan pendanaan bagi nasabah, harus diperoleh dari sumber yang benar-benar terbebas dari unsur riba. Dalam hal ini seluruh kegiatan pegadaian syariah termasuk dana yang kemudian disalurkan kepada nasabah, murni berasal dari modal sendiri ditambah dana pihak ketiga dari sumber yang dapat dipertanggungjawabkan. Pegadaian telah melakukan kerjasama dengan Bank Muamalat sebagai fundernya, kedepan pegadaian juga akan melakukan kerja sama dengan lembaga keuangan syariah lain untuk memback-up modal kerja (Soemitro, 2009: 432-434).

\section{Ar-Rahn untuk Usaha Mikro (ARRUM) Haji}

Arrum haji merupakan produk yang berasal dari Pegadaian Syariah, yang diluncurkan sebagai solusi dari produk yang ada di bank syariah yakni dana talangan haji. Yang mana produk dana talangan haji tersebut menuai perdebatan dikalangan ulama. Dengan adanya produk Arrum Haji di Pegadaian Syariah diharapkan dapat mewujudkan impian setiap umat muslim untuk beribadah ke tanah suci tanpa khawatir dengan masalah biaya. Dasar hukum dari produk Arrum Haji ini terdapat pada Fatwa Dewan Syariah Nasional Nomor 92/DSN-MUI/IV/2014 tentang pembiayaan yang disertai rahn.

Banyak kasus calon jamaah haji memiliki dana yang cukup untuk mendaftar haji, namun mereka mengalami kesulitan dalam hal pendanaan ketika menjelang pemberangkatan. Atas dasar kasus tersebut, maka dari itu Pegadaian Syariah mengeluarkan produk Arrum Haji ini. Dengan menggadaikan 3.5 gram logam mulia, akan mendapatkan pembiayaan sebesar Rp 25.000.000,- maka calon jamaah haji sudah bisa mendapatkan porsi haji dari Departemen Agama dengan mengikuti alur pendaftarannya. Dan dengan jangka waktu angsuran paling lama 5 tahun (www.pegadaiansyariah.co.id, 2019).

Keunggulan Arrum Haji diantaranya memperoleh tabungan haji yang langsung dapat digunakan untuk memperoleh nomor porsi haji, emas dan dokumen haji aman tersimpan di Pegadaian Syariah, biaya pemeliharaan barang jaminan terjangkau, dan jaminan emas dapat dipergunakan untuk pelunasan biaya haji pada saat lunas. Dalam pelaksanaannya Pegadaian Syariah juga bekerjasama dengan Bank Syariah untuk proses pembukaan rekening tabungan haji, dan proses pengantaran nasabah ke Departemen Agama. Bank yang menjadi mira tersebut diantaranya Bank BNI Syariah, Bank Mega Syariah, dan Bank Panin Syariah. 
Strategi Pemasaran Pembiayaan Arrum Haji Dalam Meningkatakan Jumlah Nasabah Di Unit Pegadaian Syariah (UPS) Cirebon Bisnis Center

Adapun persyaratan untuk akad arrum haji, diantaranya:

1. Memenuhi persyaratan sesuai Kementrian Agama untuk mendaftar haji. Persyaratan administrasi Departemen Agama, diantaranya:

a. Fotocopy KTP sebanyak 6 lembar

b. Fotocopy Kartu Keluarga sebanyak 6 lembar

c. Fotocopy Buku nikah sebanyak 3 lembar

d. Pas photo $(3 \times 4) 15$ lembar $80 \%$ wajah latar putih

e. Surat keterangan sehat dan golongan darah dari puskesmas/rumah sakit pemerintah

f. Surat keterangan domisili dari desa/kelurahan dan kecamatan

2. Fotocopy KTP yang masih berlaku

3. Menyerahkan logam mulia sseberat 3,5 gram, atau emas perhiasan berkadar minimal $70 \%$ dengan berat sekitar 7 gram.

4. Biaya administrasi Rp 270.000,-

5. Biaya pembukaan tabungan haji $\operatorname{Rp} 500.000,-$

6. Imbal jasa kafalah

Berikut ini terdapat tabel simulasi angsuran (angsuran pokok + mu'nah)

\begin{tabular}{|c|c|c|c|}
\hline $\begin{array}{l}\text { Jangka } \\
\text { Waktu }\end{array}$ & $\begin{array}{l}\text { Angsuran } \\
\text { Pokok* }\end{array}$ & $\mathrm{Mu}^{\prime} \mathrm{nah}^{* *}$ & Angsuran \\
\hline 12 Bulan & $2,083,333$ & 252,900 & $2,336,200$ \\
\hline 24 Bulan & $1,041,667$ & 252,900 & $1,294,500$ \\
\hline 36 Bulan & 694,444 & 252,900 & 947,300 \\
\hline 48 Bulan & 520,833 & 252,900 & 773,700 \\
\hline 60 Bulan & 416,667 & 252,900 & 669,500 \\
\hline
\end{tabular}

Keterangan: *Uang muka ONH

$\mathrm{SPPH}$

** Biaya pemeliharaan LM/perhiasan emas, SABPIH, dan

Tabel Pembayaran pada saat akad Arrum Haji

\begin{tabular}{r|c|r|r|r}
\hline Administrasi & Bulan & \multicolumn{1}{|c|}{ IJK } & $\begin{array}{c}\text { Tabungan } \\
\text { Bank }\end{array}$ & \multicolumn{1}{c}{ Total } \\
\hline 270,000 & 12 & 70,000 & 500,000 & 840,000 \\
\hline 270,000 & 24 & 112,500 & 500,000 & 882,500 \\
\hline 270,000 & 36 & 175,000 & 500,000 & 945,000 \\
\hline 270,000 & 48 & 265,000 & 500,000 & $1,035,000$ \\
\hline 270,000 & 60 & 412,500 & 500,000 & $1,182,500$
\end{tabular}

\section{Strategi Pemasaran}

Pemasaran adalah suatu proses dan manajerial yang membuat individu atau kelompok mendapatkan apa yang mereka butuhkan dan inginkan dengan menciptakan, menawarkan dan mempertukarkan 
Konstruksi At-Tas'īr Al-'Adl dalam Dialektika Pemikiran Ibnu Taimiyah Dan Ibnu Khaldun

produk yang bernilai kepada pihak lain atau segala kegiatan yang menyangkut penyampaian produk atau jasa mulai dari produsen sampai konsumen.

Peranan pemasaran saat ini tidak hanya menyampaikan produk atau jasa hingga tangan konsumen tetapi juga bagaimana produk atau jasa tersebut dapat memberikan kepuasan kepada pelanggan dengan menghasilkan laba. Sasaran dari pemasaran adalah menarik pelanggan baru dengan menjanjikan nilai superior, menetapkan harga menarik, mendistribusikan produk dengan mudah, mempromosikan secara efektif serta mempertahankan pelanggan yang sudah ada dengan tetap memegang prinsip kepuasan pelanggan.

Manajemen pemasaran adalah suatu usaha untuk merencanakan, mengimplementasikan (yang terdiri dari kegiatan mengorganisaikan, mengarahkan, mengkoordinir) serta mengawasi atau mengendalikan kegiatan pemasaran dalam suatu organisasi agar tercapai tujuan organisasi secara efesien dan efektif. Di dalam fungsi manajemen pemasaran ada kegiatan menganalisis yaitu analisis yang dilakukan untuk mengetahui pasar dan lingkungan pemasarannya, sehingga dapat diperoleh seberapa besar peluang untuk merebut pasar dan seberapa besar ancaman yang harus dihadapi (Shinta, 2011).

Bauran pemasaran (marketing mix) merupakan kegiatan pemasaran yang dilakukan secara terpadu. Artinya kegiatan ini dilakukan secara bersama diantara elemen-elemen yang ada dalam bauran pemasaran itu sendiri. Oleh karena itu setiap elemen membutuhkan strategi sendiri, namun tetap akan terkait dengan strategi lainnya (Nasution, 2017).

Marketing mix merupakan perangkat alat pemasaran taktis yang dapat dikendalikan; yang dipadukan oleh firm untuk menghasilkan respon yang diinginkan pasar sasaran.

Marketing mix adalah semua faktor yang dapat dikuasai oleh seseorang manajer pemasaran dalam rangka mempengaruhi permintaan konsumen terhadap barang dan jasa (Shinta, 2011). Dalam Marketing Mix kita mengenal dengan istilah $4 \mathrm{p}$ dan $3 \mathrm{p}$ yang tujuanya adalah untuk pelayanan. Dasar Marketing Mix, yaitu:

1. Product (Produk): Mengacu pada pengembangan produk atau jasa dan ditentukan oleh permintaan pasar. Pencitraan product, persepsi product, kemasan jaminan, pendukung layanan rangkaian, biaya dan paten merek dagang atau hak cipta.

2. Price (Harga): Mengacu pada biaya produksi produk atau jasa dan ditentukan oleh permintaan pasar, pencitraan produk yang kompetitif mempengaruhi keputusan penentuan harga, atribut harga meliputi: tingkat harga, kebijakan diskon, masa kredit dan metode pembayaran.

3. Promotion (Promosi): terdiri atas seluruh metode pengkomunikasian produk yang ditawarkan pada pasar yang ditargetkan. Peralatan 
Strategi Pemasaran Pembiayaan Arrum Haji Dalam Meningkatakan Jumlah Nasabah Di Unit Pegadaian Syariah (UPS) Cirebon Bisnis Center

promosi termasuk iklan yang biayanya telah dibayar, seperti televisi, radio iklan pers, iklan dibioskop, dan poster kampanye. Pemasangan iklan mengacu pada promosi penjualan yang meliputi memberikan contoh produk secara cuma-cuma, kupon diskon, persaingan, titik penjualan dan pengiriman bahan promosi secara langsung direct maling, penjualan pribadi, dan publisitas hubungan masyarakat serta dukungan sponsor.

4. Place (tempat distribusi) adalah tugas untuk membawa barang kepasar, Kemajuan dalam pemesanan tempat secara elektronik dan sistem komunitas sedang mengubah cara distribusi produk pariwisata. Distribusi termasuk saluran distribusi, pemberitaan distribusi lokasi gerai wilayah penjualan tingkat inventaris serta lokasi dan transportasi. mendahului persaingan. Pelayanan atau jasa mempunyai sifat-sifat khusus dan untuk menjelaskannya diusulkan 3P lanjutan.

5. People atau manusia. Memusatkan pada mutu sumber daya manusia yang terlibat dengan produk keterampilan, pengetahuan, motivasi serta kepedulian mereka terhadap pelanggan. Sifat-sifat karyawan termasuk keramahan, bagaimna menampilkan diri kesediaan membantu, kemampuan pendekatan, sopan santun, pengetahuan dan kopetensi.

6. Physical evidence atau bukti fisik: Perhatian dipusatkan pada sektor, lingkungan dan suasana produk atau produk mana akan dikonsumsi (penting terutama bagi pariwisata). Bentuk bukti fisik masuk ukuran, gedung, citra perusahaan, suasana, kenyamanan, dan kebersihan.

7. Proces: efisiensi dan kinerja proses akan dinilai. Sifat proses adalah kecepatan, efisiensi, waktu pelayanan, sistem pembuat janji dan formulir serta dokumen (Sunyoto, 2013).

\section{Respon Nasabah}

Respon adalah salah satu elemen dalam proses komunikasi pemasaran. Dimana respon merupakan reaksi yang diberikan oleh penerima setelah menerima pesan (Susanto, 2016). Menurut Kamus Besar Bahasa Indonesia (KBBI), respon adalah suatu tanggapan, reaksi, jawaban. Dalam kamus besar ilmu pengetahuan disebutkan bahwa, respon adalah reaksi psikologis-metabolik terhadap tibanya suatu rangsang, ada yang bersifat otomatis seperti refleksi dan reaksi emosional langsung, adapula yang bersifat terkendali (Kurniawati, 2016).

Menurut Djalaludin Rakhmat, secara umum respon atau tanggapan dapat diartikan sebagai hasil atau kesan yang didapat (ditinggal) dari pengamatan tentang subjek, peristiwa atau hubungan-hubungan yang diperoleh dengan menyimpulkan informasi dan menafsirkan pesanpesan. Menurut Soenarjo, istilah respon dalam komunikasi adalah kegiatan komunikasi yang diharapkan memunyai hasil atau setelah 
komunikasi dinamakan efek. Suatu kegiatan komunikasi itu memberikan efek berupa respon dari komunikasi terhadap suatu pesan yang dilancarkan oleh komunikator. Ahmad Subandi mengemukakan respon dengan istlah balik (feedback) yang memiliki peranan atau pengaruh yang besar dalam menentukan baik atau tidaknya suatu komunikasi. Dengan adanya respon yang disampaikan dari komunikan kepada komunikator maka akan menetralisir kesalahan penafsiran dalam sebuah proses komunikasi (Wildan al kausar, 2019).

Respon secara pemahaman luas dapat diartikan pula ketika seseorang memberikan reaksinya melalui pemikiran, sikap, dan perilaku. Sikap yang ada pada diri seseorang akan memberikan warna pada perilaku atau perbuatan seseorang. Secara umum respon atau tanggapan dapat diartikan sebagai hasil atau kesan yang didapat dari sebuah pengamatan. Adapun dalam hal ini yang dimaksud dengan tanggapan ialah pengamatan tentang subjek, peristiwa-peristiwa yang diperoleh dengan menyimpulkan informasi dan menafsirkan pesan. Segala sesuatu yang pernah kita alami akan selalu meninggalkan jejak atau kesan dalam pikiran kita. Kesan atau jejak itulah yang dapat timbul kembali dan berperan sebagai sebuah tanggapan atau bisa disebut respon (Kurniawati, 20).

\section{Faktor Terbentuknya Respon}

Tanggapan yang dilakukan seseorang dapat terjadi jika terpenuhi faktor penyebabnya. Hal ini perlu diketahui supaya individu yang bersangkutan dapat menanggapi dengan baik. Pada proses awalnya individu mengadakan tanggapan tidak hanya dari stimulus yang ditimbulkan oleh keadaan sekitar. Tidak semua stimulus yang ada persesuaian atau yang menarik darinya. Dengan demikian maka akan ditanggapi adalah individu tergantung pada stimulus juga bergantung pada keadaan individu itu sendiri. Dengan kata lain, stimulus akan mendapatkan pemilihan dan individu akan bergantung pada 2 faktor (Wildan Al Kausar, 2019: 10-11), yaitu:

a. Faktor Internal

Yaitu faktor yang ada dalam diri individu manusia itu sendiri dari dua unsur yakni rohani dan jasmani. Seseorang yang mengadakan tanggapan terhadap stimulus tetap dipegaruhi oleh eksistensi kedua unsur tersebut. Apabila terganggu salah satu unsur saja, maka akan melahirkan hasil tanggapan yang berbeda intensitasnya pada diri individu yang melakukan. tanggapan atau akan berbeda tanggapannya tersebut antara satu orang dengan orang lain. Unsur jasmani atau fisiologis meliputi keberadaan, keutuhan dan cara kerja atau alat indera, urat syaraf dan bagian- 
Strategi Pemasaran Pembiayaan Arrum Haji Dalam Meningkatakan Jumlah Nasabah Di Unit Pegadaian Syariah (UPS) Cirebon Bisnis Center

bagian tertentu pada otak. Unsur-unsur rohani dan fisiologisnya yang meliputi keberadaan dan perasaan (feeling), akal, fantasi, pandangan jiwa, mental, pikiran, motivasi, dan sebagainya.

b. Faktor Eksternal

Yaitu faktor yang ada pada lingkungan. Faktor ini intensitas dan jenis benda perangsang atau oang menyebutnya dengan faktor stimulus. Bimo walgito dalam bukunya menyatakan bahwa faktor psikis berhubungan dengan objek menimbulkan stimulus dan stimulus akan mengenai alat indera.

2. Jenis-Jenis Respon

Istilah respon dalam komunikasi adalah kegiatan komunikasi yang diharapkan mempunyai hasil atau dalam setelah komunikasi dinamakan efek. Suatu kegiatan komunikasi itu memberikan efek berupa respon dari komunikasi terhadap pesan yang dilancarkan oleh komunikator. Menurut Steven M. Chaferespon jenis-jenis respon dibedakan menjadi tiga bagian (Wildan Al Kausar, 2019: 11),, yaitu:

a. Kognitif: yaitu respon yang berkaitan erat dengan pengetahuan keterampilan dan informasi seseorang mengenai sesuatu. Respon ini timbul apabila adanya perubahan terhadap yang dipahami oleh khalayak.

b. Afektif: yaitu respon yang berhubungan dengan emosi, sikap, dan menilai seseorang terhadap sesuatu.

c. Konatif (Psikomotorik): yaitu respon yang berhubungan dengan perilaku nyata yang meliputi tindakan atau kebiasaan.

3. Macam-Macam Respon

Menurut Agus Sujanto respon terbagi menjadi bermacammacam, tanggapan/respon tersebut ialah:

a. Tanggapan menurut indera yang mengamati yaitu:

1) Tanggapan auditif, yakni tanggapan terhadap apa-apa yang telah didengarnya, baik berupa suara, kekuatan dan lain-lain.

2) Tanggapan visual, tanggapan terhadap sesuatu yang lihat.

3) Tanggapan perasa, yakni tanggapan terhadap sesuatu yang dialaminya.

b. Tanggapan menurut terjadinya, yaitu: 
Konstruksi At-Tas'īr Al-'Adl dalam Dialektika Pemikiran Ibnu Taimiyah Dan Ibnu Khaldun

1) Tanggapan ingatan, yaitu tanggapan terhadap sesuatu yang diingatnya.

2) Tanggapan fantasi, yaitu tanggapan terhadap sesuatu yang dibayangkan.

3) Tanggapan pikiran, yaitu tanggapan terhadap sesuatu yang dipikirkannya.

c. Tanggapan menurut lingkungannya yaitu:

1) Tanggapan benda, yaitu tanggapan terhadap benda yang menghampirinya atau berada didekatnya.

2) Tanggapan kata-kata, yakni tanggapan terhadap kata-kata yang didengar atau dilihatnya (Kurniawati, 28).

\section{PEMBAHASAN DAN DISKUSI}

\section{Strategi Pemasaran Pembiayaan Arrum Haji di Unit Pegadaian Syariah} CBC

Strategi pemasaran yang dilakukan oleh kantor Unit Pegadaian Syariah Cirebon Bisnis Center (CBC) terhadap khususnya produk Pembiayaan Arrum Haji menggunakan strategi marketing mix atau bauran pemasaran karena setiap elemen membutuhkan strategi sendiri, namun tetap akan terkait dengan strategi lainnya. Elemen-elemen tersebut sering disebut dengan istilah 4P, yakni Product (Produk), Price (Harga), Place (Tempat), dan Promotion (Promosi). Berikut penjelsan lebih lanjut tentang 4P (Erick Triyana, 2019), yaitu:

1. Product (Produk)

Pembiayaan Arrum Haji merupakan pengembangan dari produk Arrum (Ar-rahn untuk usaha mikro) yang ada di Pegadaian Syariah. Produk Arrum Haji ini menggunakan akad rahn, dengan menggadaikan logam mulia seberat 3.5 gram, nasabah akan mendapatkan dana pembiayaan sebesar Rp 25,000,000,-. Strategi yang diterapkan pada produk yang dijalankan oleh Pegadaian Syariah dengan memberikan fasilitas serta pelayanan yang memadai, sehingga nasabah akan merasakan kenyamanan dan merasakan kepuasan. Apabila nasabah tidak memiliki logam mulia ataupun emas yang dapat digadaikan bisa juga menggunakan tabungan emas yang dimiliki, asalkan tabungan emas tersebut telah memenuhi minimal taksiran.

2. Price (Harga)

Strategi harga mengacu pada biaya produksi produk dan ditentukan oleh permintaan pasar, pencitraan produk yang kompetitif 
Strategi Pemasaran Pembiayaan Arrum Haji Dalam Meningkatakan Jumlah Nasabah Di Unit Pegadaian Syariah (UPS) Cirebon Bisnis Center

mempengaruhi keputusan penentuan harga, atribut harga meliputi: tingkat harga, kebijakan diskon, masa kredit dan metode pembayaran. Untuk pembiayaan Arrum Haji harga yang ditawarkan merupakan harga yang sudah ditetapkan oleh kantor Pegadaian Pusat dan disesuaikan dengan kebutuhan untuk mendapatkan porsi haji. Nasabah yang membayar angsurannya lebih cepat dari jangka waktu yang telah ditetapkan maka akan mendapatkan potongan harga. Selain itu juga ada promo-promo free administrasi di waktu-waktu tertentu.

3. Place (Tempat)

Pemilihan tempat yang strategis untuk proses usaha menjadi faktor penentu kesuksesan suatu usaha yang dijalani. Dengan membandingkan dan meriset beberapa pilihan tempat yang dijadikan opsi untuk proses berjalannya usaha sebelum menentukan lokasi yang paling strategis. Lokasi yang dijadikan tempat usaha Pegadaian Syariah merupakan hasil survei dari kantor Cabang Pegadaian Syariah. Lokasi kantor Unit Pegadaian Syariah CBC cukup strategis untuk dijadikan tempat usaha, melihat jarak yang dekat dengan jalan raya serta kantor yang berdampingan dengan ruko-ruko usaha lain sehingga dapat dengan mudah untuk menarik minat nasabah.

4. Promotion (Promosi)

Promosi adalah kegiatan pendukung dalam strategi pemasaran yang dilakukan untuk menarik minat para konsumen mengenai produk yang dipasarkan. Promosi yang dilakukan Pegadaian Syariah terhadap produk Arrum Haji dengan cara cross selling yaitu menawarkan produk secara langsung kepada nasabah yang berkunjung ke outlet Pegadaian Syriah maupun kepada nasabah yang berkunjung ke kantor Cabang Pegadaian Syariah, strategi promosi selanjutnya dengan mengadakan seminar haji, mendatangi pengajianpengajian yang didalamnya terdapat kegiatan promosi dan sosialisasi produk Arrum Haji, mengadakan program mitra dakwah untuk merekrut pesrta haji. Selain itu Pegadaian Syariah juga melakukan promosi melalui media seperti iklan di televisi dan media massa, dan memasang banner-banner di stasiun dan bandara.

\section{Mekanisme Pelaksaan Pendaftaran Haji}

Pembiayaan Arrum Haji menjadi pilihan bagi nasabah Pegadaian Syariah untuk mewujudkan impiannya pergi ke tanah suci. Selain biaya yang terjangkau juga prosedur yang harus dipenuhi juga tidak rumit. Selain itu, usia 12 tahun sudah diperbolehkan mendaftar Arrum Haji, dan usia maksimal yang diperbolehkan mendaftar yaitu 60 tahun. Saat ini produk Arrum Haji sudah bisa diwariskan, apabila terjadi hal-hal yang tidak memungkinkan nasabah yang mendaftar Arrum Haji untuk berangkat ke tanah suci. 
Konstruksi At-Tas'īr Al-'Adl dalam Dialektika Pemikiran Ibnu Taimiyah Dan Ibnu Khaldun

Dari hasil pengamatan yang saya lakukan di kantor Unit Pegadaian Syariah Cirebon Bisnis Center pada nasabah yang mengajukan pembiayaan ARRUM Haji mekanisme pelaksanaan pendaftaran haji meliputi langkah-langkah sebagai berikut:

1. Nasabah mendatangi kantor pegadaian untuk mengajukan permohonan pembiayaan ARRUM Haji.

2. Nasabah menyiapkan persyaratan dan ketentuan yang diperlukan untuk pengajuan pembiayaan ARRUM Haji.

3. Menyerahkan marhun emas kepada Pegadaian Syariah untuk proses penaksiran oleh bagian penaksir.

4. Mengisi formulir permohonan pembiayaan ARRUM Haji.

5. Pihak Pegadaian akan menghubungi pihak Bank yang menjadi Mitra untuk proses selanjutnya.

6. Nasabah mendatangi pihak Bank untuk membuka rekening tabungan haji dan memperoleh dokumen Setoran Awal Biaya Penyelenggaraan Ibadah Haji (SABPIH) dari bank, setoran awal biaya haji sebesar Rp $500,000,-$.

7. Mendatangi kantor Kementrian Agama untuk memproses dan memperoleh nomor porsi atau Surat Pendaftaran Porsi Haji (SPPH).

8. Menyerahkan SABPIH, SPPH, buku tabungan haji ke pegadaian sebagai jaminan selain emas yang dijaminkan diawal akad.

\section{Respon Nasabah terhadap Produk Pembiayaan ARRUM Haji}

Kendala yang seringkali dihadapi pada produk arrum haji tedapat pada masyarakat yang beranggapan bahwa pemberangkatan haji dilakukan setelah angsuran dilunasi. Sedangkan yang menentukan kuota haji dan pemberangkatannya dilakukan oleh Departemen Agama. Selain itu kendala yang dihadapi adalah persepsi masyarakat yang beranggapan bahwa pegadaian yang akan membimbing nasabah sampai pada waktu pemberangkatan, padahal yang membimbing nasabah adalah pihak bank mitra. Peran pegadaian hanya sebagai media untuk mendapatkan pendanaan dari barang yang dijaminkan. Karena setelah angsuran selesai/lunas maka antara nasabah dengan pihak pegadaian sudah tidak memiliki ikatan lagi, dan barang-barang yang menjadi jaminan akan dikembalikan kembali. Barang-barang yang menjadi jaminan tersebut adalah logam mulia/emas, buku tabungan, SABPIH, dan SPPH (Erik Triyana, 2019).

Respon yang diberikan oleh nasabah yang menggunakan produk Pembiayaan Arrum Haji sangat baik. Nasabah merasa terbantu dengan adanya produk Arrum Haji, karena mempercepat untuk mendapatkan porsi haji, dan meringankan dari segi materi. Secara pembayaran yang dilakukan dengan angsuran kepada Pegadaian Syariah dan marhun yang dititipkan kepada murtahin akan dikembalikan setelah pelunasan. 
Strategi Pemasaran Pembiayaan Arrum Haji Dalam Meningkatakan Jumlah Nasabah Di Unit Pegadaian Syariah (UPS) Cirebon Bisnis Center

Kebanyakan nasabah Arrum Haji mengetahui produk ini dari Kantor Pegadaian Syariah yang mereka kunjungi, nasabah mengetahui dari tawaran karyawan Pegadaian Syariah dan secara melihat langsung dari bosur yang ada. Secara prosedur tidak memberatkan nasabah, namun terdapat kendala dari nasabah sendiri pada saat pengumpulan persyaratan. Ketika melampirkan surat keterangan domisili, sedikit ada kendalan karena memang nasabah sering berpindah-pindah tempat tinggal. Tempat yang disediakan juga cukup strategis karena dekat dengan tempat bekerja. Dan memang kantor Unit Pegadaian Syariah CBC terletak di jalan Tuparev yang notabene lingkungan perkantoran. Adapun alasan yang dituturkan mengapa memilih mengikuti program ibadah haji dari Pegadaian Syariah karena memang menginginkan segala prosesnya menggunakan prinsip syariah dan Pegadaian Syariah merupakan perusahan yang secara SOP menggunakan prinsip syariah (Tini, 2019).

\section{KESIMPULAN}

Berdasarkan pada uraian pembahasan dan diskusi di atas, penulis menyimpulkan tiga poin, pertama strategi pemasaran yang dilakukan oleh kantor Unit Pegadaian Syariah Cirebon Bisnis Center (CBC) terhadap Pembiayaan Arrum Haji menggunakan strategi marketing mix atau bauran pemasaran 4P, yakni strategi Product (produk), pembiayaan Arrum Haji dengan memberikan fasilitas serta pelayanan yang memadai, sehingga nasabah akan merasakan kenyamanan dan merasakan kepuasan. Strategi Price (harga), pembiayaan Arrum Haji sudah ditetapkan oleh kantor Pegadaian Pusat dan disesuaikan dengan kebutuhan untuk mendapatkan porsi haji. Strategi Place (tempat), yang dijadikan tempat usaha Pegadaian Syariah merupakan hasil survei dari kantor Cabang Pegadaian Syariah. Lokasi kantor Unit Pegadaian Syariah CBC cukup strategis untuk dijadikan tempat usaha, melihat jarak yang dekat dengan jalan raya serta kantor yang berdampingan dengan ruko-ruko usaha lain sehingga dapat dengan mudah untuk menarik minat nasabah. Strategi Promotion (promosi), yang dilakukan Pegadaian Syariah terhadap produk Arrum Haji dengan cara cross selling, mengadakan seminar haji, mendatangi pengajian-pengajian, mengadakan program mitra dakwah untuk merekrut pesrta haji. Selain itu Pegadaian Syariah juga melakukan promosi melalui media seperti iklan di televisi dan media massa, dan memasang banner-banner di stasiun dan bandara.

Kedua, mekanisme pelaksanaan pendaftaran Arrum Haji meliputi langkah-langkah berikut pertama, nasabah mendatangi kantor pegadaian untuk mengajukan permohonan pembiayaan ARRUM Haji. Kedua, nasabah menyiapkan persyaratan dan ketentuan yang diperlukan untuk pengajuan pembiayaan ARRUM Haji. Ketiga, menyerahkan marhun emas kepada Pegadaian Syariah untuk proses 
Konstruksi At-Tas'īr Al-'Adl dalam Dialektika Pemikiran Ibnu Taimiyah Dan Ibnu Khaldun

penaksiran oleh bagian penaksir. Keempat, mengisi formulir permohonan pembiayaan ARRUM Haji. Kelima, pihak Pegadaian akan menghubungi pihak Bank yang menjadi Mitra untuk proses selanjutnya. Keenam, nasabah mendatangi pihak Bank untuk membuka rekening tabungan haji dan memperoleh dokumen Setoran Awal Biaya Penyelenggaraan Ibadah Haji (SABPIH) dari bank, setoran awal biaya haji sebesar Rp 500,000,-. Ketujuh, mendatangi kantor Kementrian Agama untuk memproses dan memperoleh nomor porsi atau Surat Pendaftaran Porsi Haji (SPPH). Kedelapan, menyerahkan SABPIH, SPPH, buku tabungan haji ke pegadaian sebagai jaminan selain emas yang dijaminkan diawal akad.

Ketiga, respon yang diberikan oleh nasabah yang menggunakan produk Pembiayaan Arrum Haji sangat baik. Nasabah merasa terbantu dengan adanya produk Arrum Haji, karena mempercepat untuk mendapatkan porsi haji, dan meringankan dari segi materi. Secara pembayaran yang dilakukan dengan angsuran kepada Pegadaian Syariah dan marhun yang dititipkan kepada murtahin akan dikembalikan setelah pelunasan. Secara prosedur tidak memberatkan nasabah, namun terdapat kendala dari nasabah sendiri pada saat pengumpulan persyaratan. Ketika melampirkan surat keterangan domisili, sedikit ada kendalan karena memang nasabah sering berpindah-pindah tempat tinggal. Tempat yang disediakan juga cukup strategis karena dekat dengan tempat bekerja. Adapun alasan yang dituturkan mengapa memilih mengikuti program ibadah haji dari Pegadaian Syariah karena memang menginginkan segala prosesnya menggunakan prinsip syariah dan Pegadaian Syariah merupakan perusahan yang secara SOP menggunakan prinsip syariah.

\section{DAFTAR PUSTAKA}

Afrizal. Metodologi Penelitian Kualitatif. Depok: PT RajaGrafindo Persada, 2016.

Brosur-brosur dan Data-data Lainnya. Cirebon: Pegadaian Syariah, 2019.

Fatmala, Wiki. "Analisis Strategi Pemasaran Poduk Arrum Haji dalam Meningkatkan Jumlah Nasabah (Study Kasus Pegadaian Unit Pelayanan Syariah Way Halim)", Skripsi. Lampung: Universitas Islam Negeri Raden Intan Lampung, 2018.

Fuad, Muhammad, "Analisis Peran Pembiayaan Oleh Pegadaian Syariah Bagi Pengembangan UMKM (Studi Kasus Produk Ar-Rum di Kota Langsa)", Jurnal j-EBIS, Vol. 3, No. 2 (Juni, 2018).

https://kbbi.web.id/respons. Diakses pada 22 September 2019.

https://pegadaiansyariah.co.id/arrum-haji. Diakses pada tanggal 14 September 2019. 
Strategi Pemasaran Pembiayaan Arrum Haji Dalam Meningkatakan Jumlah Nasabah Di Unit Pegadaian Syariah (UPS) Cirebon Bisnis Center

Jauhariatuzzuhdiyah. "Pengaruh Prosedur Pembiayaan Arrum Haji Terhadap Keputusan Nasabah dalam Menggunakan Jasa pada Pegadaian Syariah (Study Kasus Pegadaian Syariah Cabang Balauran Dan Pegadaian Syariah Cabang Sidoarjo)“, Skripsi. Surabaya: Universitas Islam Negeri Sunan Ampel Surabaya, 2018.

Kausar, Wildan Al. "Respon Masyarakat Kota Malang Terhadap City Branding 'Beautiful Malang'”, Skripsi. Malang: Universitas Muhammadiyah Malang, 2018.

Kurniawati, Erna. "Respon Mahasiswa IAIN Kendari Terhadap Dakwah Jurnalisme Online", Skripsi. Kendari: IAIN Kendari, 2016.

Manfaat, Budi dan Toto S. N. Dasar-Dasar Metodologi Penelitian. Cirebon: Eduvision, 2015.

Nasution, Siti Nasroh. "Analisis Marketing Bank Syariah Mandiri dalam Meningkatkan Pembiayaan BSM Implan", Skripsi. Medan: Universitas Islam Negeri Sumatera Utara, 2017.

Shinta, Agustina. Manajemen Pemasaran. Malang: UB Press, 2011.

Soemitra, Andri. Bank dan Lembaga Keuangan Syariah. Edisi Kedua Jakarta: Kencana, 2009.

Sunyoto, Danang. Manajemen Pemasaran (Pendekatan Konsep, Kasus, dan Psikologi Bisnis. Yogyakarta: Center of Academic Publishing Service (CAPS), 2013.

Susanto, Tabitha E. "Pesan dan Respon dalam Proses Komunikasi Pemasaran Kafe Melalui Instagram", Jurnal E-Komunikasi. Vol. 4, No. 1, 2016.

Widodo. Metodologi Penelitian. Depok: PT RajaGrafindo Persada, 2017. 